\title{
CDK12 Gene
}

National Cancer Institute

\section{Source}

National Cancer Institute. CDK12 Gene. NCI Thesaurus. Code C101095.

This gene is involved in protein phosphorylation, RNA splicing and transcription elongation. 